\title{
THE EFFECT OF METEORIC PHREATIC DIAGENESIS AND SPRING SAPPING ON THE FORMATION OF SUBMARINE COLLAPSE STRUCTURES IN THE BIAK BASIN, EASTERN INDONESIA
}

\author{
David P. Gold* \\ SE Asia Research Group, Department of Earth Sciences, Royal Holloway University of London, Egham, \\ Surrey, TW20 OEX, United Kingdom
}

*Corresponding author: david.patrick.gold@gmail.com

\begin{abstract}
The islands of Biak and Supiori, situated in the Bird's Head region of New Guinea, comprise predominantly Neogene age carbonate units that extend offshore into the adjacent Biak Basin. Unusual geomorphologic features including pockmarks, headless canyons and semi-circular collapse structures identified in multibeam bathymetric imagery occur on the southern margin of the Biak Basin. These features have a bathymetric expression distinct from strike-slip faults of the Biak Fault Zone which bound the eastern margin of the basin. The Biak Fault Zone comprises several seismically active, segmented and parallel fault strands. Seismicity along the Biak Fault Zone is responsible for the shedding of mass transport deposits into the basin, however these are absent from the geomorphologic features along the southern margin of the basin. Instead, these features appear isolated and unrelated to activity of the Biak Fault Zone and are interpreted to have formed as a result of 'spring sapping' by submarine aquifers. Rapid uplift during the Pliocene caused exposure and karstification of carbonates from onshore Biak which extend into the offshore Biak Basin, providing conduits for a freshwater lens to develop within older Miocene strata. Diagenetic cement textures and fabrics indicate that many Miocene carbonates were subjected to meteoric diagenesis within freshwater aquifers that overprinted burial cements. This is supported by stable isotope analyses of diagenetic cements which record negative $\delta^{18} \mathrm{O}$ values.
\end{abstract}

Keywords: Spring sapping, meteoric diagenesis, carbonates, aquifer

\section{INTRODUCTION}

The islands of Biak and Supiori are situated in the Indonesian province of Papua on the Pacific island of New Guinea. These islands form part of a small archipelago of islands north of Cenderawasih Bay, a large embayment to the west of New Guinea (Figure 1). Biak is the largest island within this archipelago, with the island of Supiori located to the northwest. The islands of Biak and Supiori are separated by the Sorendidori Fault (Figure 1), an oblique normal fault that downthrows younger Neogene sediments of the island of Biak to the SE from Early to Middle Miocene carbonates of the island of Supiori to the NW (Gold et al., 2017). Neogene sediments from Biak and Supiori are predominantly carbonates that extend SW into the offshore Biak Basin, which is situated south of Biak and Supiori, and north of
Yapen Island (Figure 1). The Biak Basin is bounded on its eastern margin by the Biak Fault Zone, a series of parallel, NW-SE trending strike-slip faults that form the linear west coast of Supiori and Biak (Gold et al., 2017). These faults also form clearly expressed lineaments on the seafloor that are readily observed in multibeam bathymetric data (Gold et al., 2017; Figure 1).

Several unusual geomorphologic collapse features are observed along the southern margin of the offshore Biak Basin (Figure 1). This study aims to test whether these features are fault-controlled or diagenetic in origin by examining the bathymetric expression of structural features of the basin using multibeam imagery and the burial history of analogous outcrop samples collected from formations that extend offshore. This paper 


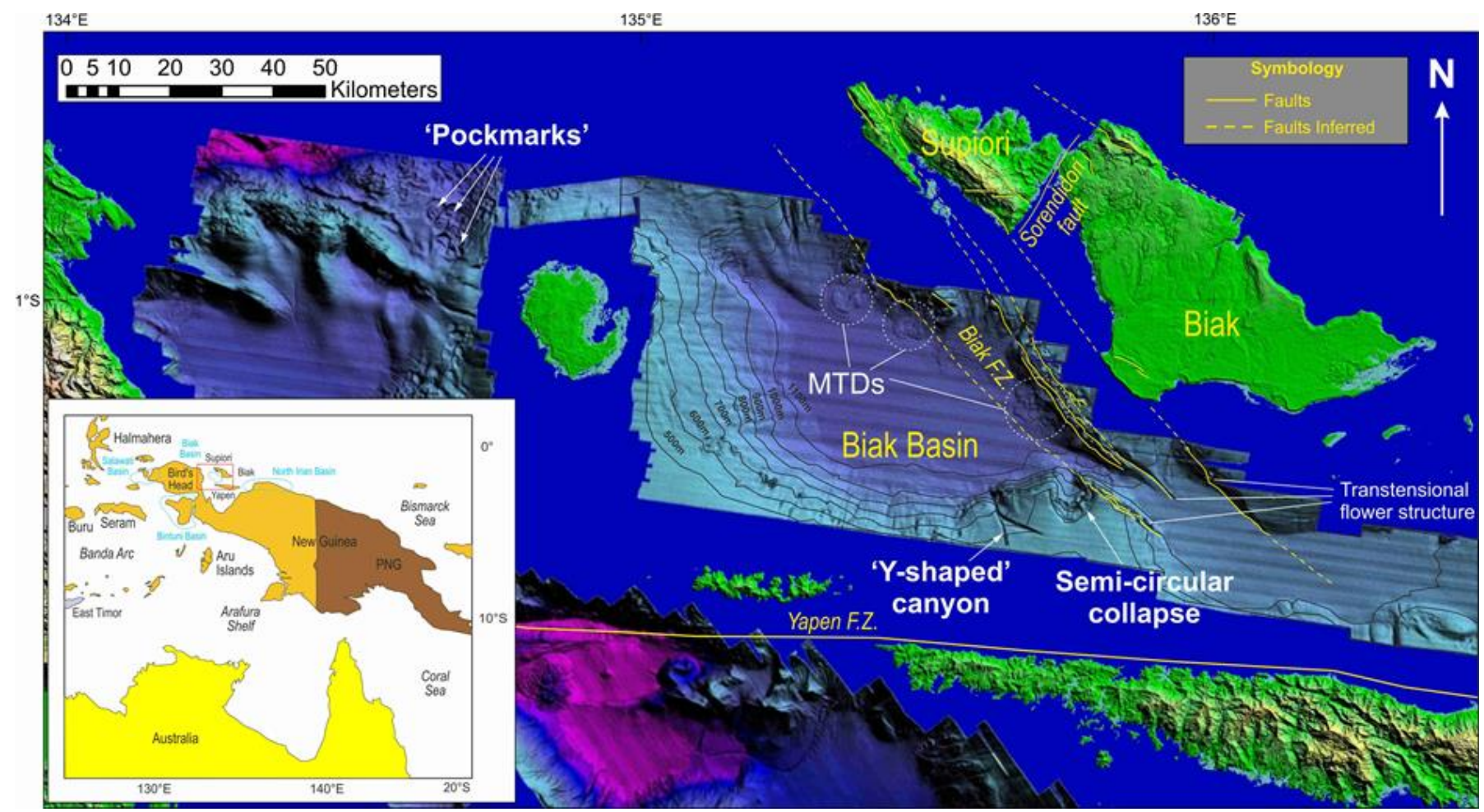

Figure 1: ASTER digital elevation and bathymetric multibeam data provided by TGS of the Biak Basin and islands of Biak and Supiori displaying key structural and bathymetric features (MTDs - Mass transport deposits).

contributes to the understanding of geomorphologic and diagenetic responses to regional tectonic events in a frontier basin of Eastern Indonesia through application of laboratory techniques to identify the sedimentary processes that control geomorphologic features.

\section{NEOGENE GEOLOGICAL HISTORY}

During the Early to Middle Miocene, carbonate platforms flourished across much of the Bird's Head and are recorded in outcrop and the Salawati, Bintuni, and Biak Basins. These carbonates form part of the 'New Guinea Limestone Group' which includes several contemporaneous carbonate formations found across much of western New Guinea (Visser and Hermes 1962; Pieters et al., 1983; Brash et al., 1991; Gold et al., 2017). From the Middle to Late Miocene, a reduction of carbonate accumulation rates due to environmental deterioration which were outpaced by the rate of relative sea-level rise led to the drowning of the New Guinea Limestone Group platform beneath deepwater strata (Gold et al., 2017).

Rapid uplift of New Guinea, validated by fission track ages of metamorphic units, is recorded from $10 \mathrm{Ma}$, and in many areas since $5 \mathrm{Ma}$ (Hill and Gleadow, 1989). This culminated in the formation of the regional 'intra-Pliocene unconformity', dated within the Salawati basin to have occurred at approximately 4 Ma (Decker et al., 2009). This unconformity is related to rapid uplift of the MisoolOnin-Kumawa ridge, an arcuate anticline subparallel to what is now the Seram Trough (Pairault et al., 2003). The collision of the Banda Arc with the Australian margin in the Timor area caused large scale surface deformation across the Bird's Head and Banda Arc from slab-mantle decoupling (Spakman and Hall, 2010). The rapid isostatic uplift resulting from this decoupling caused the formation of this unconformity and the rapid exhumation of the Neogene sediments.

The Biak Fault Zone is interpreted to be a young feature as it incises Pliocene strata (Gold et al., 2017). Recent sedimentation within the Biak Basin is controlled by activity along the Biak Fault Zone (Bertoni and Garcia 2012; Memmo et al., 2013).

\section{INVESTIGATION OF OFFSHORE FEATURES}

'Pock marks', headless canyons and semi-circular collapse features observed in bathymetric multibeam data occur several kilometres offshore south-west of the island of Biak (Figure 1). In multibeam data, a narrow 'Y-shaped' headless canyon-oriented NW-SE is approximately $10 \mathrm{~km}$ in length and $700 \mathrm{~m}$ wide (Figure 1). Approximately 20 $\mathrm{km}$ east of this structure, a semi-circular collapse feature is approximately $7 \mathrm{~km}$ in diameter (Figure 1). 
The potential for these structures to be faultcontrolled or diagenetic in origin was examined.

\section{Active faulting on the Biak margin}

The 'Y-shaped' canyon and semi-circular collapse structure are situated west of NW-SE striking segments of the Biak Fault Zone which forms a transtensional flower structure to the east of the Biak Basin (Figure 1). The orientation of the 'Yshaped canyon' and semi-circular collapse structures is also NW-SE and are parallel to the strike of the Biak Fault Zone (Figure 1). Recent earthquake CMT focal mechanisms in the Biak and Supiori region plotted between 1st January 1976 and 1st January 2018 show that the Biak Fault Zone is currently seismically active (Figure 2). Focal mechanisms indicate that presently principal displacement along the Biak Fault Zone has a dextral strike-slip component along a NW-SE striking plane parallel to the orientation of the faults identified in multibeam bathymetry (Figure 2). Lobate mass transport deposits (MTDs) are common along strands of the Biak Fault Zone, indicating the shedding of material during fault movement (Figure 2), however they are absent from the collapse structures on the southern margin of the Biak Basin. The 'Y-shaped' canyon displays no evidence for seismicity within the last 40 years, nor is it associated with any MTDs (Figure 2). The semicircular collapse structure is associated with an earthquake that occurred on 24th November 1990 at a depth of $15 \mathrm{~km}$, however this may be related to the slumping of overlying material into the collapse feature.

The surface expression of the 'Y-shaped' canyon and semi-circular collapse feature is markedly different to that of the Biak Fault Zone (Figures $1 \& 2$ ). Segments of pure strike-slip often appear as straight or wavy faults of modest topographic expression (Le Pichon et al., 2001). This is clearly shown along the

135 136

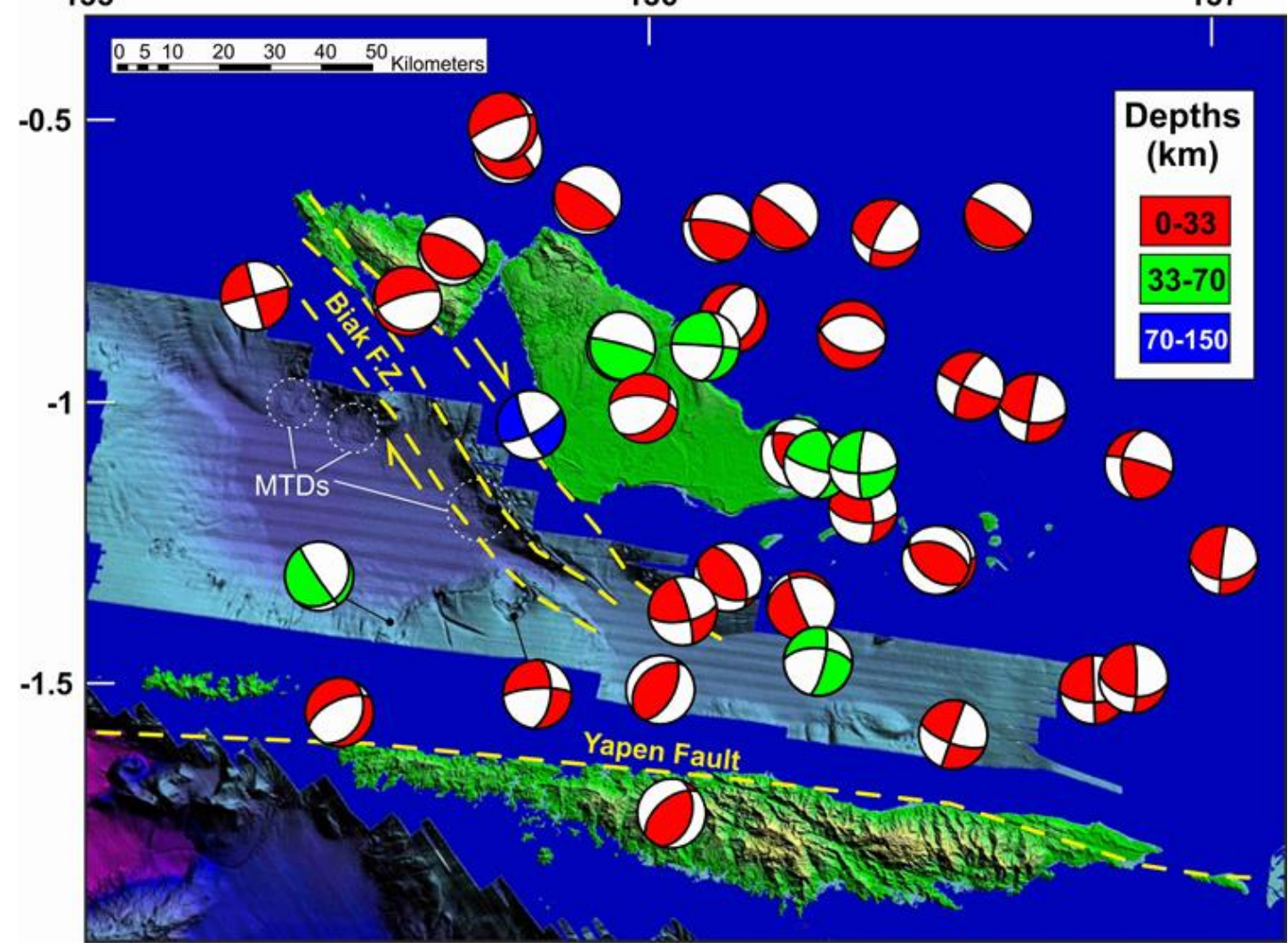

Figure 2: Recent earthquake CMT focal mechanisms in the Biak and Supiori region plotted from the International Seismological Centre catalogue using MIRONE software in between 1st January 1976 to 1st January 2018. Focal mechanisms are plotted over ASTER DEM and multibeam bathymetric imagery. Mass transport deposits (MTDs) are common along strands of the Biak Fault Zone (Biak F.Z.) which exhibit a predominantly dextral strike-slip component along computed fault planes that are parallel to structures observed in multibeam bathymetry. MTDs are absent from the collapse structures on the southern margin of the Biak Basin. The ' $Y$-shaped' canyon displays no evidence for seismicity within the last 40 years, nor is it associated with any MTDs. The circular collapse structure is associated with an earthquake that occurred on 24th November 1990 at a depth of $15 \mathrm{~km}$ displaying oblique slip with either a dextral N-S component, possibly relating to the Biak F.Z., or a sinistral E-W component. However, this earthquake may also have been related to the collapse of overlying material into an undercut cavity. 
principal strands of the Biak Fault Zone which are laterally continuous, with evidence for displacement and high relief fault scarps between minor faults parallel to the main strands of the transtensional flower structure (Figure 1). In contrast, the ' $Y$ shaped' canyon is observed in low relief except for a deep narrow incision along its central course. Neither the 'Y-shaped' canyon nor the semi-circular collapse feature display evidence for displacement or lateral continuity. It is, therefore, interpreted that these structures are isolated and are not faultcontrolled by activity of the Biak Fault Zone.

\section{Submarine spring sapping}

The erosional undercutting of a slope results in mass wasting of overlying material (Orange and Breen, 1992) and is known by a variety of terms including 'seepage erosion' (Hutchinson, 1968), 'artesian sapping' (Milton, 1973) and 'spring sapping' (Johnson, 1939; Small, 1965; Bates and Jackson, 1980; Robb, 1990). In this article the term submarine spring sapping is favoured. There are many examples of where spring sapping has resulted in the formation of submarine canyons worldwide (e.g. Johnson, 1939, Robb, 1984; Paull and Neumann, 1987; Paull et al, 1990; Robb, 1990; Orange and Breen, 1992; Orange et al., 1994; Dugan and Flemings, 2000; 2002; Green et al., 2007; Flemings et al., 2008; Bratton, 2010).

Lateral migration of meteoric water within marine basins is well documented (Wu and Chafetz, 2002; Bratton, 2010). Bratton (2010) defined three spatial scales of submarine groundwater discharge: 1) nearshore - 0-10 m offshore, 2) embayment - $10 \mathrm{~m}$ - $10 \mathrm{~km}$ offshore, 3) shelf - width of the entire continental shelf. Fresh water has been reported in a well $100 \mathrm{~km}$ off shore Florida in the Gulf of Mexico, $10 \mathrm{~km}$ offshore of Saudi Arabia and offshore Bahrain in the Persian Gulf, and beneath the continental shelves of the North Atlantic (Kohout, 1966; Fetter, 1980; Chafetz et al., 1988; Chafetz and Rush, 1995; Edmonds, 2001; Wu and Chafetz, 2002; Person et al., 2003; Fleury et al., 2007). Meteoric diagenesis of ancient carbonates through lateral flow of fresh water in palaeoaquifers is also well-documented (Grover and Read, 1983; Dorobek, 1987; Niemann and Read, 1987; Wu and Chafetz, 2002; Moore and Wade, 2013).

Submarine spring sapping results in headward erosion and slope undercutting that leads to repeated slope failure and the formation of gullies and/or canyons (Orange and Breen, 1992). Orange and Breen (1992) attribute the cause of spring sapping to be seepage induced slope failure controlled by critical pore pressure gradients whereby flow through a porous medium exacts a force on grains greater than the frictional or cohesive force holding the grains in place and material is transported away leading to slumping of overlying material. It has been suggested that this process may be the most significant mechanism for causing slope failure leading to the development of headless canyons (Johnson, 1939; Sangrey, 1977).

Due to the isolated nature of the collapse features, and their tendency to form headless canyons, the potential for these structures to be created through a process of submarine spring sapping was examined. Carbonate units that are exposed on the islands of Biak and Supiori are interpreted to extend into the offshore Biak Basin (e.g. Gold et al., 2014). Therefore, samples were collected from Biak and Supiori to determine whether evidence for meteoric diagenesis is observed onshore in units interpreted to be present in the subsurface of the Biak Basin

\section{MATERIAL AND METHODS OF ONSHORE ANALOGUE ANALYSES}

Fieldwork was conducted in 2011 and 2013 on the islands of Biak and Supiori. Carbonates were described in the field and sampled for analysis at Royal Holloway, University of London. In total 47 samples were selected for petrographic analyses using thin section petrography to determine their post-depositional burial history. Cement types observed during petrographic analysis were divided into those that form in meteoric waters, the marine realm, and shallow and deep burial environments based on features described by Tucker and Wright (1990) and Scholle and Ulmer-Scholle (2003), and depicted in Figure 3.

Nine samples (Biak 1-5, Supiori 1-4) deemed representative of the varying diagenetic cement types identified through thin section petrography were later selected for bulk-rock stable isotope $\left(\delta^{18} \mathrm{O}\right.$ and $\delta^{13} \mathrm{C}$ ) analyses to determine the presence of meteoric cements. Samples were milled to extract powdered calcite specifically from areas in which cements were abundant, avoiding bioclastic grains to ensure bulk isotope values indicative of diagenetic cement. Carbon dioxide was extracted from samples by reacting the milled powder with phosphoric acid using the procedure described by McCrea (1950). Three standards were used to fix the calibration curve, NBS19, LSVEC, and RHBNC. RHBNC is the Royal Holloway standard taken from Iceland spar which forms at low temperatures. One standard was used for NBS19 and LSVEC, and three samples of RHBNC were used as a control to monitor the run. Analytical precision, based on the RHBNC standard, was less than $0.05 \%$ o for both oxygen and carbon ratios (Table 1). Consistency of results was achieved by comparing laboratory standards against NBS19 using the calibration curve. The stable isotope data are recorded in relation to the heavier isotope $\left(\delta^{18} \mathrm{O}\right.$ and $\delta^{13} \mathrm{C}$ ), and Peedee Belemnite (VPDB) standard. 


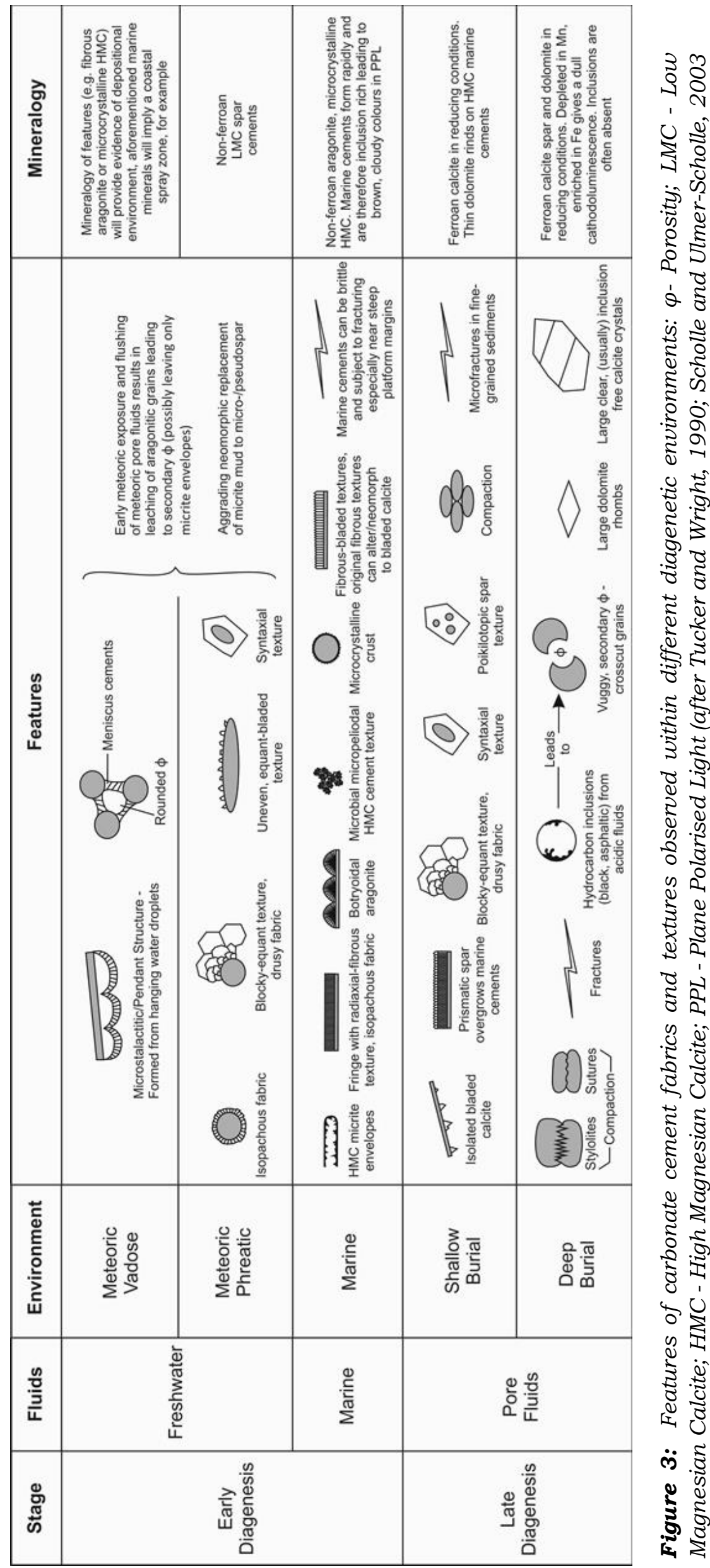




\section{PETROGRAPHIC ANALYSIS}

The diagenetic features of the samples including porosity forming episodes, cross cutting relationships, and overgrowth of cements was examined (Figure 4). Different carbonate cement textures and fabrics form within different diagenetic environments relating to the chemistry of the waters they are bathed in, saturation with respect to carbonate, and levels of oxygen upon burial (Figure 2).

\section{Description}

Samples Biak 1 of the Pleistocene age Mokmer Formation and Supiori 1 of the Early Miocene age Wainukendi Formation are classified as grainstones which contain inclusion-rich fibrous fringes and botryoidal cements, with intervening primary interparticle porosity (Figure 4). The remainder of the samples which are Pliocene age or older (Biak 25, Supiori 2-4) contain abundant isopachous or uneven bladed calcite cements fringing grains, porefilling inclusion-free equant calcite cements and a packstone fabric undergoing aggrading neomorphism of originally aragonitic micrite to calcite micro- or pseudospar (Figure 4). This fabric is later cross cut by the development of secondary mouldic porosity (Figure 4).

\section{Interpretation}

Samples from the relatively young Pleistocene age sediments of the Mokmer Formation are interpreted to have been deposited in a reefal environment on the reef crest and reef front. These environments are home to photosynthetic organisms and high hydrodynamic energies that act to remove $\mathrm{CO}_{2}$ away from the site of deposition. This increases alkalinity and encourages precipitation of early marine cements such as fibrous fringes that often do not fully occlude interparticle pore space (Figures $3 \& 4$ ).

Sediments influenced by meteoric phreatic diagenesis are characterized by pervasive calcitization of aragonite, extensive dissolution with well-developed mouldic porosity, and the occurrence of isopachous bladed and pore-filling equant calcite cements (Quinn, 1991; Figures 3 \& 4). Meteoric diagenesis is often responsible for aggressive dissolution and porosity enhancement due to undersaturation of meteoric waters with respect to

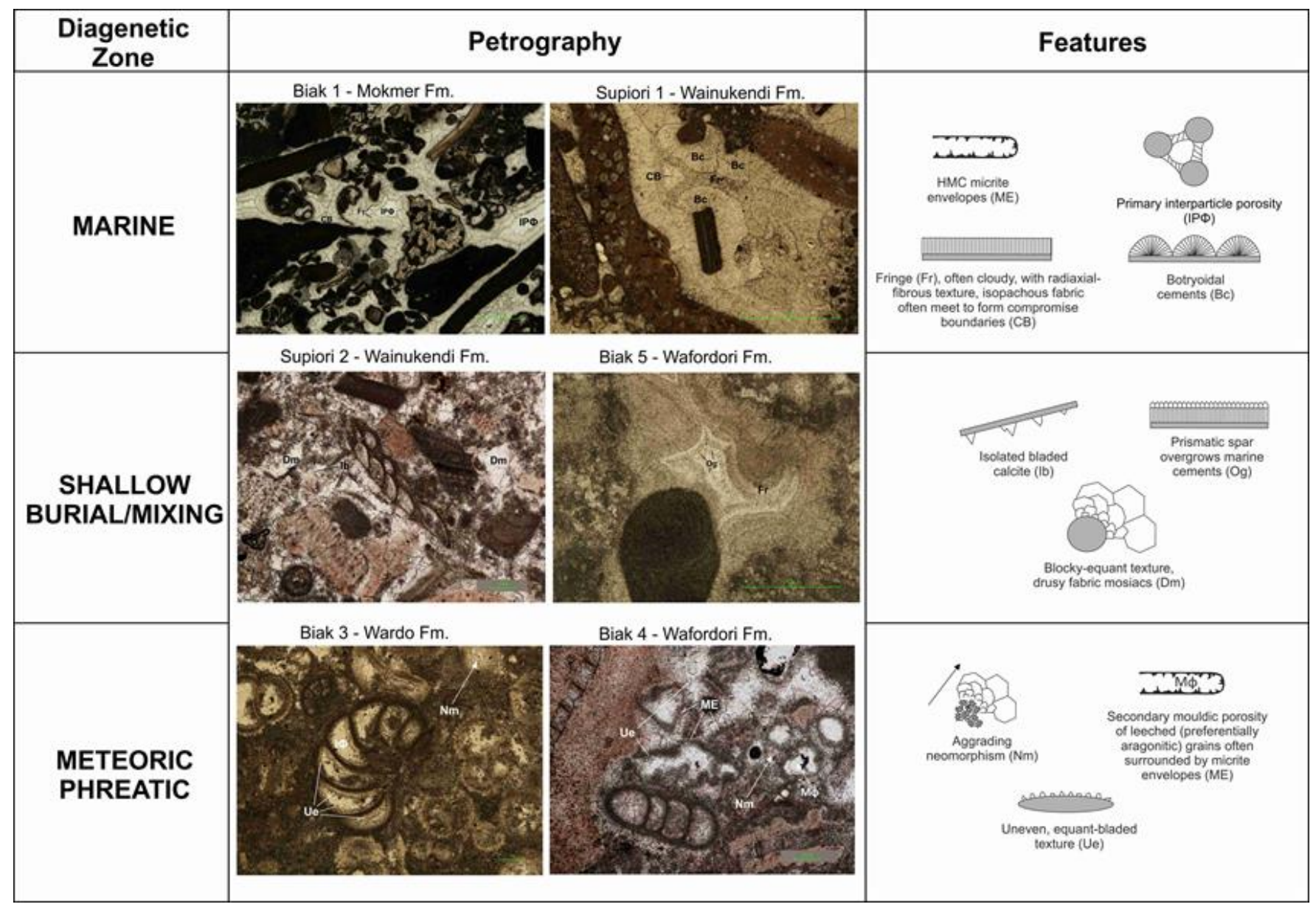

Figure 4: Thin section photographs in plane polarised light of cement textures and fabrics observed during petrographic analysis of samples. Different cement textures and fabrics are observed to be characteristic of the marine, shallow burial and meteoric phreatic diagenetic realms. 
calcite and the development of secondary mouldic porosity (Tucker and Wright, 1990). These characteristics are observed in samples from Pliocene and older sediments, with the exception of sample Supiori 1 of the Wainukendi Formation. It is therefore interpreted that onshore samples from Biak and Supiori were subject to pervasive overprinting by meteoric cements which is likely to extend into the offshore. This supports Hendardjo and Netherwood's (1986) observations from the nearby Salawati Basin where most offshore samples were subject to meteoric phreatic diagenesis after burial.

Through petrographic analyses a paragenetic sequence of cement phases precipitated with increasing time and burial was determined based on cross-cutting and over-printing relationships (Figure 5). Over printing relationships suggest that they underwent diagenesis in a meteoric phreatic environment late on during their paragenetic history (Figure 5).

\section{RESULTS OF STABLE ISOTOPE ANALYSIS}

The results of the bulk-rock stable isotope analyses are given in Table 1 . The results show that calcite comprised $>94 \%$ of the powdered carbonate material in all but one sample. Sample Biak 3 of the Korem Formation contained only ca. $70 \%$ calcite. The $\delta^{18} \mathrm{O}$ values of the calcite cements range from -5.36 to $1.48 \%$ VPDB (Table 1 ) and the $\delta^{13} \mathrm{C}$ values range from -7.61 to $+2.74 \%$ VPDB (Table 1 ). Carbon- oxygen cross plots of the analysed samples are shown in Figure 6.

The results of the stable isotope analysis indicate that the majority of the cements show a trend from precipitation in normal shallow marine waters to precipitation in the meteoric phreatic diagenetic realm, supporting observations made through petrographic analysis (Figure 6). Meteoric cements have negative $\delta^{18} \mathrm{O}$ values as fresh water is more enriched with the lighter $16 \mathrm{O}$ isotope. However, during late diagenesis pore fluids also often exhibit negative $\delta^{18} \mathrm{O}$ values, and less negative $\delta^{13} \mathrm{C}$, (Figure 6) due to higher temperatures of precipitation on burial and fractionation (Dickson and Coleman, 1980; Tucker and Wright, 1990).

Samples Biak 1 and Supiori 1 of the Mokmer and Wainukendi Formations, respectively, plot close together in the low positive end of $\delta^{18} \mathrm{O}$ and $\delta^{13} \mathrm{C}$ values (Figure 5). Both these samples exhibit very obvious early marine diagenetic features such as inclusion-rich fibrous fringes and botryoidal cements (Figure 4), and plot with carbon and oxygen isotope values expected for normal marine carbonate cements (Figure 6). Samples from the Wardo (Biak 2-3) and Wafordori (Biak 4-5) Formations exhibit highly negative $\delta^{18} \mathrm{O}$ values between -3.79 and $-5.36 \%$ VPDB, typical of values expected of meteoric phreatic cements (Figure 6). The oldest Early Miocene samples from the Wainukendi Formation (Supiori 2-3) fall within the mixing zone between normal marine and meteoric phreatic cements (Figure 5). However, sample Supiori 4 of the Wainukendi Formation exhibits $\delta^{18} \mathrm{O}$

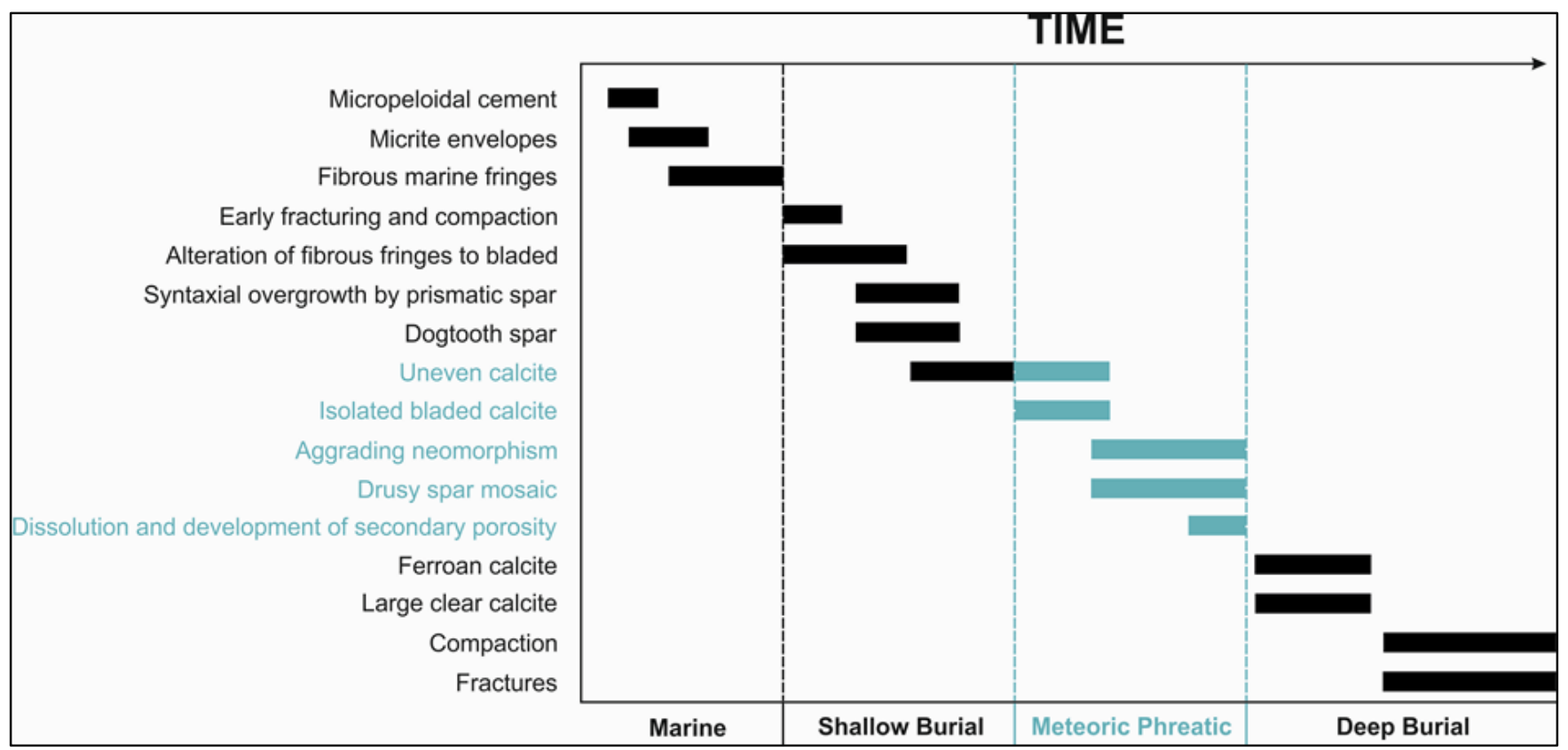

Figure 5: Paragenetic scheme of cement phases forming with increasing time and burial. Evidence for diagenesis in the marine, shallow burial, meteoric phreatic and deep burial diagenetic realms is interpreted. Based on overprinting relationships, the meteoric phreatic diagenetic realm is encountered late on in the paragenetic sequence. 
Table-1 : Oxygen and carbon isotope data including standards and precision information. The stable isotope data are recorded in relation to the heavier isotope $\left(\delta^{18} \mathrm{O}\right.$ and $\left.\delta^{13} \mathrm{C}\right)$, and Peedee Belemnite (VPDB) standard. Isotopic composition of sea water taken from Shackleton and Kennett (1975). Temperature calculated using method described by Anderson and Arthur (1983). Calculated burial depth using a geothermal gradient of $3^{\circ} \mathrm{C} / 100 \mathrm{~m}$.

\begin{tabular}{|c|c|c|c|c|c|c|c|c|}
\hline Samples & Formation & Age & $\delta^{13} C(\%)$ & $\delta^{18} \mathrm{O}(\%)$ & $\begin{array}{l}\text { Est \% } \\
\text { carb. }\end{array}$ & $\begin{array}{c}\delta^{18} \mathrm{O} \text { sea } \\
\text { water }\end{array}$ & $\begin{array}{c}\text { Temp } \\
\left({ }^{\circ} \mathrm{C}\right)\end{array}$ & $\begin{array}{l}\text { Depth } \\
\text { (m) }\end{array}$ \\
\hline \multirow{2}{*}{\multicolumn{9}{|c|}{ Standards }} \\
\hline & & & & & & & & \\
\hline RHBNC & & & 3.31 & -10.37 & 95.49 & & & \\
\hline RHBNC & & & 3.23 & -10.35 & 102.36 & & & \\
\hline RHBNC & & & 3.22 & -10.42 & 96.00 & & & \\
\hline Average & & & 3.25 & -10.38 & 97.95 & & & \\
\hline $\begin{array}{l}\text { External } \\
\text { Precision }\end{array}$ & & & 0.04 & 0.03 & & & & \\
\hline NBS-19 & & & 1.94 & -2.20 & 100.00 & & & \\
\hline Known & & & 1.95 & -2.20 & & & & \\
\hline LSVEC & & & -46.50 & -26.70 & 112.37 & & & \\
\hline Known & & & -46.50 & -26.70 & & & & \\
\hline \multicolumn{9}{|l|}{ Outcrop } \\
\hline Biak 1 & Mokmer & Pleistocene & 2.66 & -1.48 & 94.34 & -1.20 & 17.2 & 572.3 \\
\hline Biak 2 & Wardo & Pliocene & -7.21 & -5.03 & 97.52 & -1.20 & 33.8 & 1126.0 \\
\hline Biak 3 & Wardo & Pliocene & -6.95 & -3.79 & 71.92 & -1.20 & 27.6 & 920.5 \\
\hline Biak 4 & Wafordori & Middle - Early Miocene & -7.61 & -4.81 & 98.23 & -1.20 & 32.6 & 1087.7 \\
\hline Biak 5 & Wafordori & Middle - Early Miocene & -2.44 & -5.36 & 98.96 & -1.20 & 35.5 & 1182.5 \\
\hline Supiori 1 & Wainukendi & Early Miocene & 2.74 & -1.71 & 97.73 & -1.20 & 18.1 & 604.8 \\
\hline Supiori 2 & Wainukendi & Early Miocene & 0.34 & -2.52 & 95.91 & -1.20 & 21.7 & 723.5 \\
\hline Supiori 3 & Wainukendi & Early Miocene & 0.84 & -3.11 & 96.77 & -1.20 & 24.4 & 813.4 \\
\hline Supiori 4 & Wainukendi & Early Miocene & 0.61 & -4.56 & 95.64 & -1.20 & 31.4 & 1046.8 \\
\hline
\end{tabular}

and $\delta^{13} \mathrm{C}$ values approaching those expected for deep burial cements (Figure 5).

The results of the bulk-rock stable isotope analyses allowed palaeothermometry calculations to determine temperatures at which the cements precipitated. A geothermal gradient of $3^{\circ} \mathrm{C} / 100 \mathrm{~m}$ was calculated from bottom-hole temperatures in the similar Salawati (Redmond and Koesoemadinata, 1976), Bintuni (Chevallier and Bordenave, 1986), and North Irian (McAdoo and Haebig, 1999) regional basins was used to convert temperature to depth.

The method for calculating palaeodepths and precipitation temperatures was taken from work on the cement stratigraphy of Miocene carbonates from Sabah, Malaysia (Ali, 1995). It was assumed that the parameters of Ali's (1995) method would closely match that of the Biak Basin since samples used in both experiments were of similar age, latitude, geothermal and hydrothermal gradients, and were likely to have similar starting sea-water temperatures and isotopic values.

To equate the calculated $\delta^{18} \mathrm{O}_{\mathrm{VPDB}}$ values obtained by mass spectroscopy to burial depth, it is necessary to know the isotopic composition of the ambient pore fluids, the geothermal gradient for the time of each cement stage, and the degree of openness of the system (Ali, 1995). As the isotopic composition of the pore fluids is unknown, it is impossible to relate the $\delta^{18}$ OVPDB values precisely to a burial depth. However, an estimate of palaeo-precipitation temperature can be given using Equation 1. This equation follows a standard palaeotemperature calculation given by Epstein et al. (1953), later refined by Irwin et al. (1977) and Anderson and Arthur (1983), and used by Ali (1995) on Miocene carbonates from Sabah.

$$
T=16.0-4.14\left(\delta_{c}-\delta_{w}\right)+0.13\left(\delta_{c}-\delta_{w}\right)^{2}
$$


Where:

$\mathrm{T}=$ precipitation temperature $\left({ }^{\circ} \mathrm{C}\right)$

$\delta \mathrm{c}=$ oxygen isotopic composition of $\mathrm{CO}_{2}$ produced from calcite at $25^{\circ} \mathrm{C}$

$\delta \mathrm{w}=$ oxygen isotopic composition of $\mathrm{CO}_{2}$ in equilibrium with formation water, given as $-1.2 \%$ for seawater composition prior to the establishment of polar ice caps (Shackleton and Kennett, 1975; Ali, 1995).

$$
\mathrm{D}=\mathrm{T} / \mathrm{Gg}
$$

Where:

$\mathrm{D}=\operatorname{depth}(\mathrm{m})$

$\mathrm{T}=$ precipitation temperature $\left({ }^{\circ} \mathrm{C}\right)$ calculated using Equation 1

$\mathrm{Gg}=$ geothermal gradient, here given as $3^{\circ} \mathrm{C} / 100 \mathrm{~m}$ $(0.03)$
Using the $3^{\circ} \mathrm{C} / 100 \mathrm{~m}$ geothermal gradient, maximum burial depth can be calculated using Equation 2. From the recorded values of $\delta^{18} \mathrm{O}$, it is calculated that meteoric cements from sample Biak 5 of the Wafordori Formation attained the greatest burial depth and temperature values of ca. $1.2 \mathrm{~km}$ and $c a .35 .5^{\circ} \mathrm{C}$, respectively (Table 1 ).

\section{DISCUSSION}

\section{Synthesis of petrographic and stable isotopic data}

Carbonate cements that have undergone meteoric phreatic diagenesis specifically related to subaerial exposure are reported to display variable $\delta^{13} \mathrm{C}$ values with relatively constant $\delta 18 \mathrm{O}$ values (Allan and Matthews, 1982). However, relatively constant $\delta^{13} \mathrm{C}$ and variable $\delta^{18} \mathrm{O}$ values are an indicator of meteoric
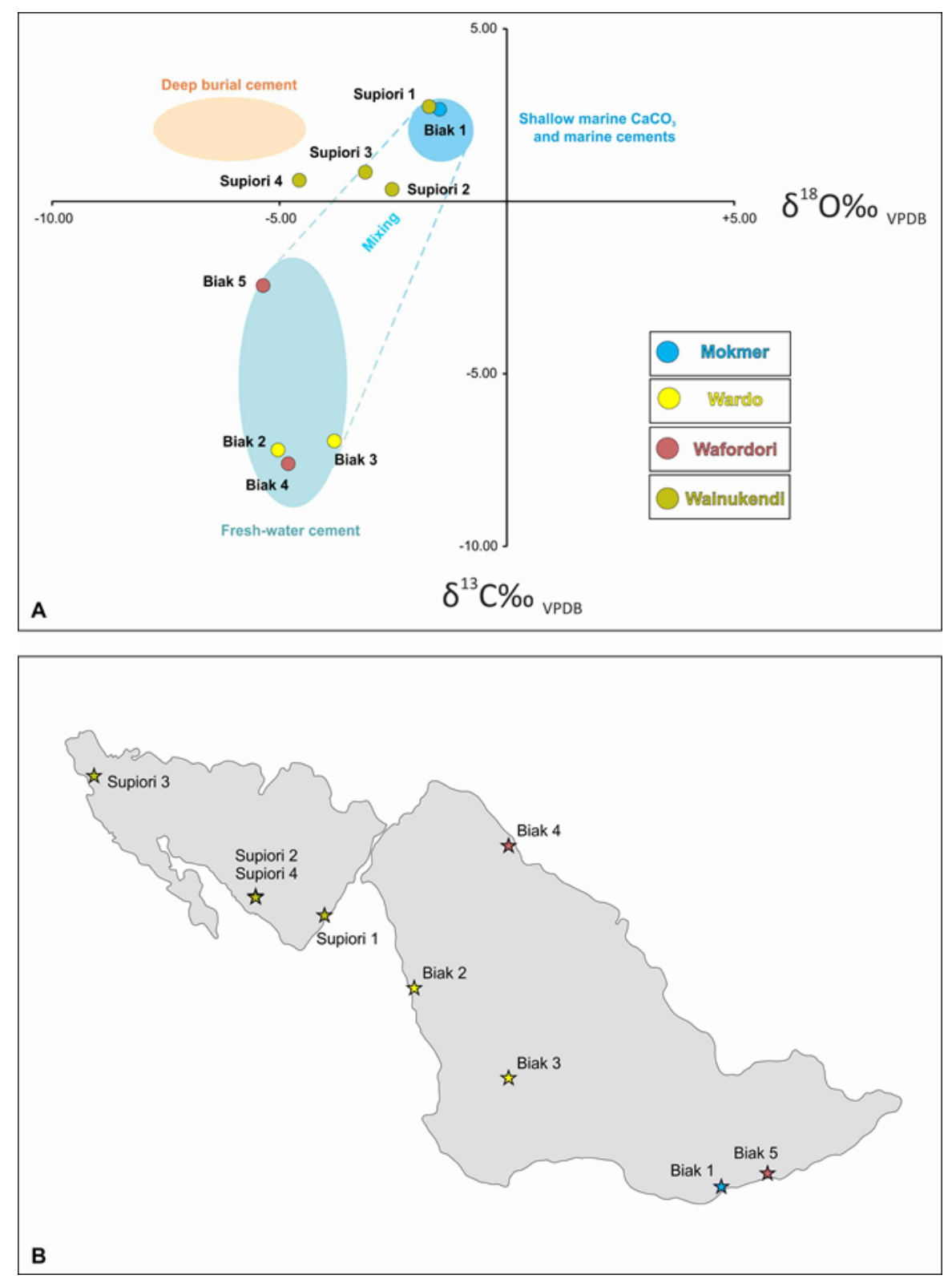

Figure 6: A) Carbon-oxygen cross plots for Neogene carbonate samples analysed for stable isotope geochemistry. Samples Biak 1 and Supiori 1 which display obvious marine cements lay within the carbon and oxygen isotopic values expected for the precipitation of marine cements. There is a trend towards freshwater cements occurring during burial, supporting the interpretation of a submarine freshwater aquifer beneath the burial diagenetic environment. B) Location map of samples collected from the islands of Biak and Supiori 
diagenesis at relatively low water-rock ratios (Wu and Chafetz, 2002). Samples from Biak and Supiori display increasingly negative $\delta^{18} \mathrm{O}$ and $\delta^{13} \mathrm{C}$ values which indicate considerable water-rock interactions suggesting meteoric waters had a progressively greater influence on the isotopic composition of samples during burial (e.g. Wu and Chafetz, 2002).

Observations of overprinting of cements indicate that meteoric diagenesis occurred late on in the paragenesis of the carbonate samples (Figure 5). This is supported by the temperatures calculated for the precipitation of meteoric cements during stable isotope analysis which suggest they were precipitated at depths ca. $1 \mathrm{~km}$ (Table 1). During the Early to Middle Miocene, carbonates originally formed in the marine diagenetic environment were progressively buried, passing through underlying diagenetic environments precipitating deeper burial cements (Figure 5).

Samples dated from the Early Miocene through to the Pliocene are interpreted to have attained burial depths of approximately $1.2 \mathrm{~km}$ (Table 1). This

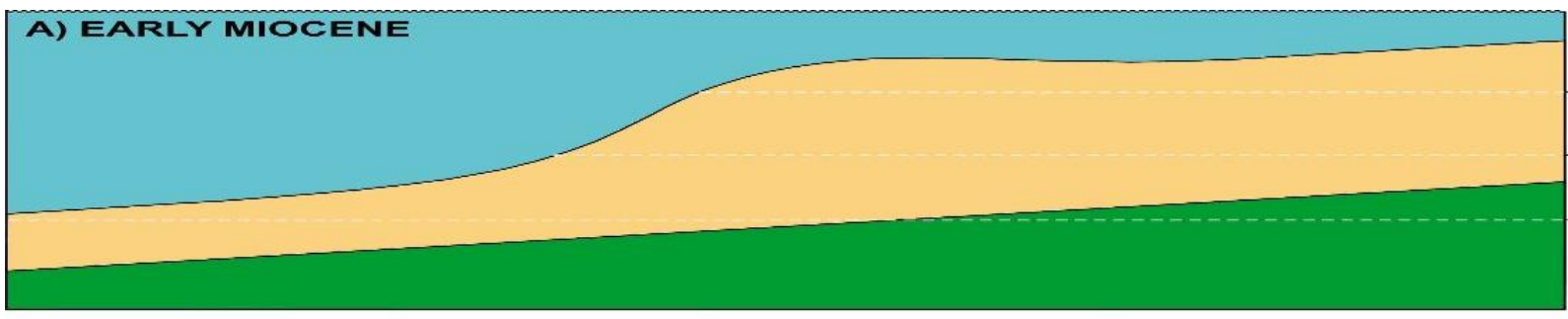

Elagenetic

Marine

Shallow

Deep

Deepest

B) MIDDLE MIOCENE

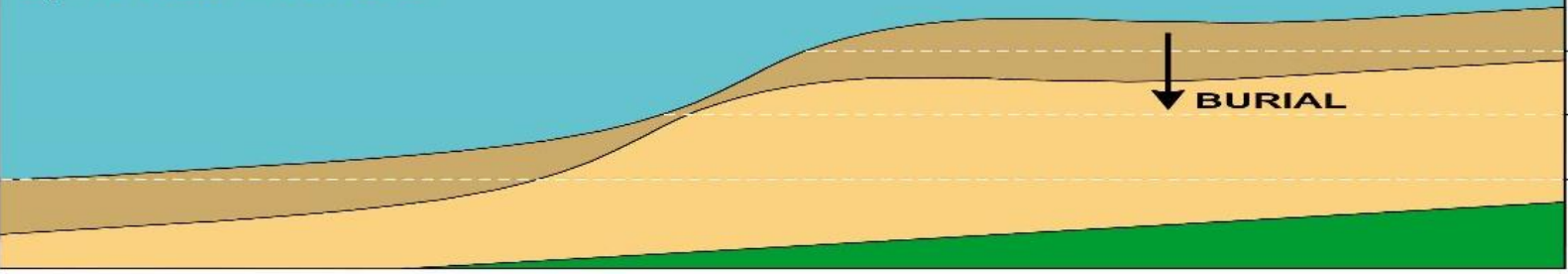

Marine

Shallow

Deep

Deepest

C) LATE MIOCENE

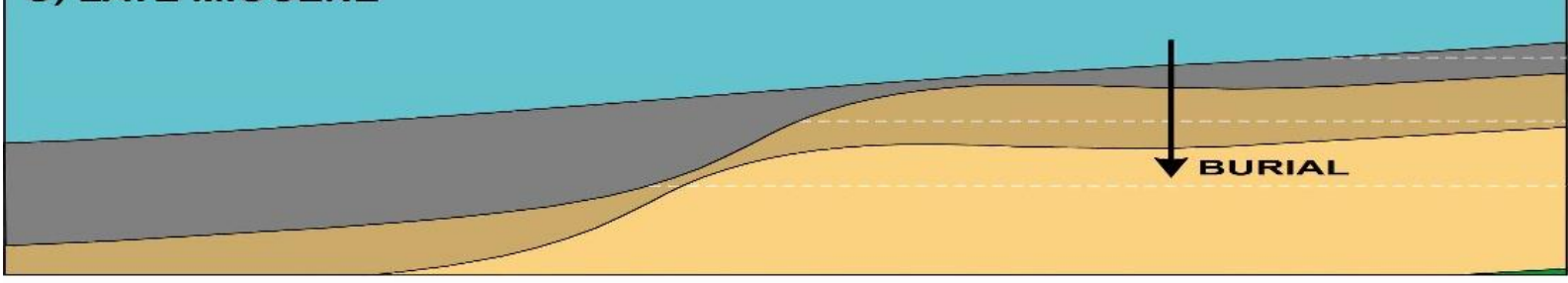

Marine

Shallow

Deep

Deepest

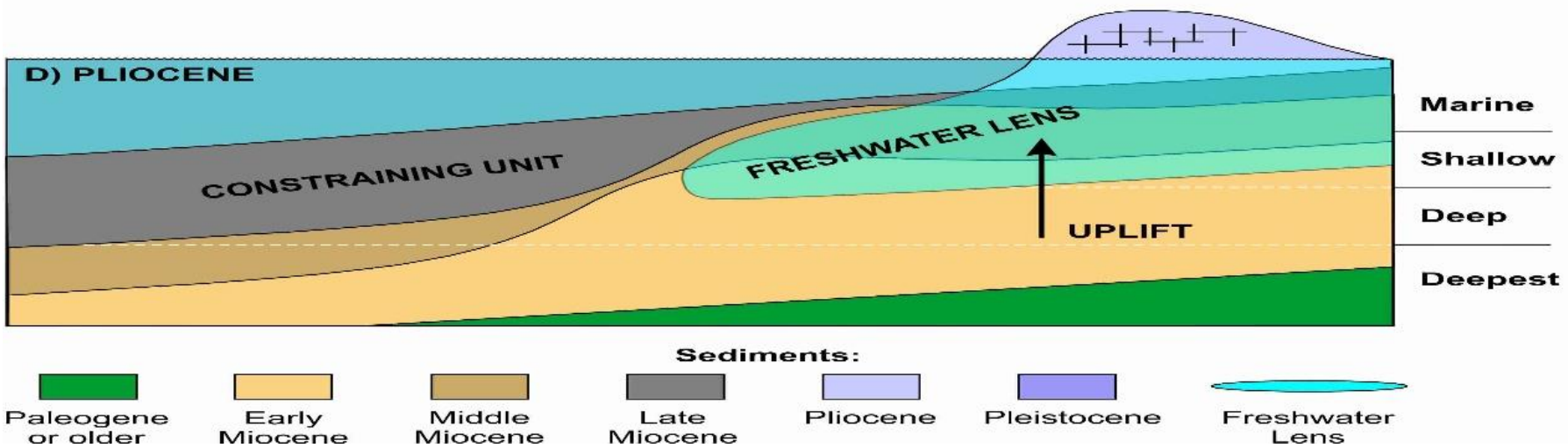

Figure 7: Schematic model showing development of the freshwater lens during the Neogene. A) During the Early Miocene, carbonate platforms grow within marine diagenetic realms, burying older to deeper burial diagenetic environments, B) As relative sea-level rises, Middle Miocene carbonate strata backstep across former Early Miocene platform, burying it within the shallow burial diagenetic realm, C) As relative sea-level continues to rise, the Early Miocene platform is progressively buried to deeper diagenetic environments, D) Uplift forming the intra-Pliocene unconformity exposes Pliocene sediments. Karstification forms conduits for freshwater lens to develop and penetrate older strata. Strata previously buried within deep diagenetic environments are uplifted into meteoric realm causing overprinting of meteoric diagenesis over burial cements. The oldest sediments are not uplifted far enough to reach fresh water lens and retain deepest burial diagenetic signature. 
suggests relatively rapid uplift of Neogene strata since the Pliocene. There may have been gradual burial of carbonate strata in the Bird's Head region up to the Pliocene until the formation of the regional 'Intra-Pliocene' unconformity at $4 \mathrm{Ma}$ (Decker et al., 2009) which is responsible for the rapid exhumation of Neogene sediments.

Meteoric phreatic diagenesis within carbonate rocks is usually attributed to periods of low relative sealevel, especially within shallow water facies rocks (Meyers and Lohmann, 1985; Quinn, 1991; Frank and Lohmann, 1995; Melim, 1996; Moore and Wade, 2013). Karstic joints that are developed in subaerially exposed carbonates of the hinterland act as a conduit for freshwater aquifers to extend offshore. In the Biak and Supiori region, relative sealevel lowstand is attributed to the tectonic uplift, exhumation subaerial exposure and karstification of the youngest Neogene sediments during the formation of the 'Intra-Pliocene' unconformity (Figure 7). Karstic joints acted as conduits for freshwater to develop a subterranean lens bathing older strata in meteoric waters. It is interpreted that this freshwater lens is the cause of meteoric phreatic diagenesis within samples analysed by this study. The process of exhumation uplifted strata previously buried within deep diagenetic environments up into the region influenced by the freshwater lens, causing overprinting of meteoric cements on interpreted burial cements (Figure 7).

Some of the oldest Early Miocene samples from the Wainukendi Formation exhibit carbon and oxygen isotopic values close to those expected for deep burial cements (Figure 6). It is interpreted that these samples have not been uplifted through the freshwater lens, and are exposed updip of the lens
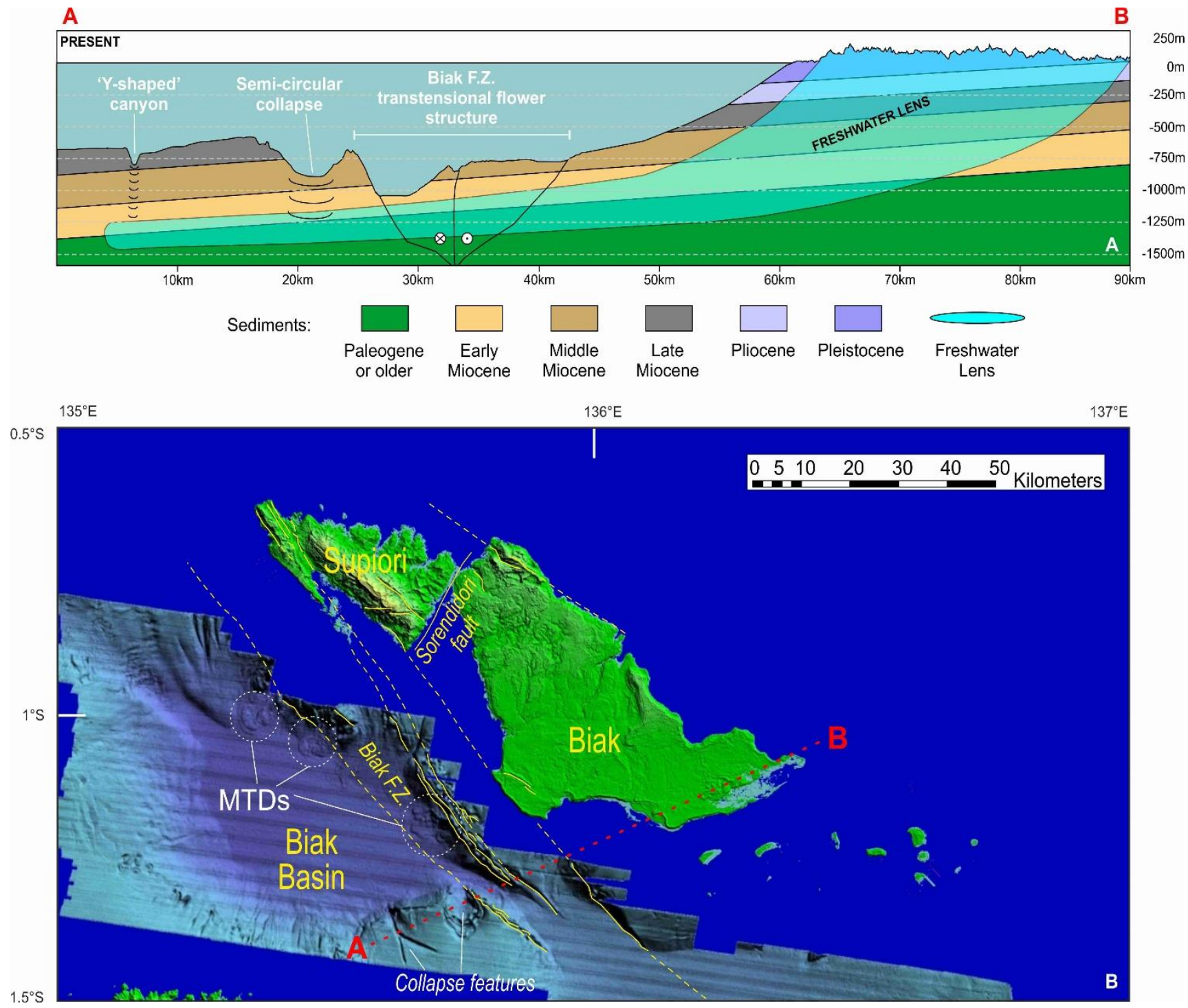

Figure 8: A) Present day topographic and bathymetric profile along transect $A-B$ across southern Biak and into the offshore Biak Basin. The freshwater lens extends southwest from the island beneath the Biak basin, comparable to the Floridian Aquifer. B) Transect A-B displayed in map view across the southern margin of the Biak Basin 
on the island of Biak. Inversely, the youngest Pleistocene sediments have not been buried to such an extent to have reached the freshwater lens, and remain unaffected by meteoric diagenesis (Figure 8).

\section{Effect of meteoric diagenesis in the Biak Basin}

'Pock mark' and collapse features, such as those observed west of Biak and Supiori (Figure 1), are often associated with gas seepage (e.g. Hovland and Judd, 1998; Yun et al., 1999). However, here they are interpreted to be caused by submarine 'spring sapping'. The process of submarine spring sapping is interpreted to be driven by the freshwater lens responsible for the meteoric phreatic overprinting of samples collected onshore Biak and Supiori extending a considerable distance offshore (Figure 8). The Biak and Supiori aquifer extending offshore into the Biak Basin represents the shelf scale of Bratton (2010). At the shelf scale the freshwater aquifer extends as far as the shallowest overlying confining unit, typically comprising fine-grained sediments (Bratton, 2010). The confining unit in Biak and Supiori are interpreted to be Late Miocene to Pliocene deep-water sediments (e.g. Gold et al., 2017). The thickness of the meteoric lens at the shelf scale is typically several hundred metres and has a width of approximately $80 \mathrm{~km}$ (Bratton, 2010). In the offshore Biak Basin, the width of the lens extends approximately $55 \mathrm{~km}$ offshore and is interpreted to be approximately $250 \mathrm{~m}$ thick (Figure 8). The interpreted ca. $1 \mathrm{~km}$ depth of the Biak freshwater lens is comparable to that of the Floridian Aquifer and extends almost as far offshore (Figure 8).

It is unknown whether the 'Y-shaped' canyon or semi-circular collapse feature observed in multibeam bathymetry (Figure 8) formed during subaerial exposure or subaqueously. However, it is likely that both are relatively recent structures, no older than the Pliocene. The lateral, rather than vertical, displacement of carbonate units by the Biak Fault Zone permitted the freshwater lens to extend beyond the transtensional flower structure via welldeveloped karstic joints acting as conduits to the southern margin of the Biak Basin.

\section{CONCLUSIONS}

Petrographic and stable isotope analysis of Neogene carbonates from the Bird's Head region of New Guinea enables the reconstruction of their subsequent burial history and potential as hydrocarbon reservoirs. The following conclusions can be drawn from these reconstructions.

Calculation of burial temperatures and depths reached by samples suggest that they attained a maximum temperature of ca. $35.5^{\circ} \mathrm{C}$ and depth of ca. $1.2 \mathrm{~km}$ up until the Pliocene. Sediments were rapidly exhumed during the creation of the intraPliocene unconformity' formed when rapid isostatic uplift as slab-mantle decoupling close to Timor affected the wider Banda Arc and Bird's Head region. This uplift resulted in a period of low relative sealevel in the Biak and Supiori region with the development of a freshwater aquifer formed as a response. Most samples show evidence of meteoric phreatic diagenesis through petrographic recognition of meteoric cements and presence of light oxygen isotopes. Precipitation of these cements is interpreted to have occurred late on in the paragenetic history of the samples as they passed through a freshwater lens during uplift. Subsequent 'spring sapping' by this freshwater lens is responsible for various collapse structures observed in multibeam bathymetry of the Biak Basin.

\section{ACKNOWLEDGMENTS}

I would like to thank TGS for providing multibeam bathymetric data, Ramadhan Adhitama and Ferry Yulien of Institut Teknologi Bandung for assistance during field work and collection of the samples, the Southeast Asia Research Group consortia and staff members at Royal Holloway, University of London for enabling this study to take place, Dr. Dave Lowry and Dr. Nathalaie Grassineau for help in stable isotope analysis, and Dr. Jim Hendry for continued support and assistance in the production of the isotope cross plot. Finally, I would like to thank Robert Hall for continued mentoring, guidance, helpful discussion and facilitating the progression of our understanding of a geologically complex and exciting region of the world through his work with the Southeast Asia Research Group.

\section{FUNDING}

This research was funded by industrial companies as part of a consortium supporting the Southeast Asia Research Group at Royal Holloway, University of London.

\section{REFERENCES CITED}

Ali, M. Y., 1995. Carbonate cement stratigraphy and timing of diagenesis in a Miocene mixed carbonate-clastic sequence, offshore Sabah, Malaysia: constraints from cathodoluminescence, geochemistry, and isotope studies. Sedimentary Geology 99 (3), 191-214.

Allan, J.R., Matthews, R.K., 1982. Isotope signatures associated with early meteoric diagenesis. Sedimentology 29(6), 797-817. 
Bertoni, C., Garcia, J.A., 2012. Interplay between Submarine Depositional Processes and Recent Tectonics in the Biak Basin, Western Papua, Eastern Indonesia. Berita Sedimentologi 23, 42-45.

Bratton, J.F., 2010. The three scales of submarine groundwater flow and discharge across passive continental margins. The Journal of Geology 118(5), 565-575.

Chafetz, H. S., McIntosh, A. G., Rush, P.F., 1988. Freshwater diagenesis in the marine realm of recent Arabian Gulf carbonates. Journal of Sedimentary Petrology 58 (3), 433-440.

Chafetz, H.S., Rush, P.F., 1995. Two-phase diagenesis of Quaternary carbonates, Arabian Gulf: Insights from d13C and d 180 data. Journal of Sedimentary Research A65, 294-305.

Chevallier, B., Bordenave, M. L., 1986. Contribution of geochemistry to the exploration in the Bintuni Basin, Irian Jaya. Proceedings Indonesian Petroleum Association, 15th Annual Convention and Exhibition, Jakarta, 439-460.

Decker, J., Bergman, S.C., Teas, P.A., Baillie, P., Orange, D.L., 2009. Constraints on the tectonic evolution of the Bird's Head, West Papua, Indonesia. Proceedings Indonesian Petroleum Association, 33rd Annual Convention and Exhibition, Jakarta, 491514, IPA-G-139.

Dickson, J.A.D., Coleman, M.L., 1980. Changes in carbon and oxygen isotope composition during limestone diagenesis. Sedimentology 27(1), 107-118.

Dorobek, S.L., 1987. Petrography, geochemistry, and origin of burial diagenetic facies, SiluroDevonian Helderberg Group (carbonate rocks), Central Appalachians. AAPG Bulletin $71,492-514$.

Dugan, B., Flemings, P.B., 2002. Fluid flow and stability of the U.S. continental slope offshore New Jersey from the Pleistocene to the present. Geofluids 2,137-146.

Dugan, B., Flemings, P.B., 2000. Overpressure and fluid flow in the New Jersey Continental Slope: implications for slope failure and cold seeps. Science 289, 288-291.

Epstein, S., Buchsbaum, R., Lowenstam, H.A., Urey, H.C., 1953. Revised carbonate-water isotopic temperature scale. Geological Society of America Bulletin 64 (11), 1315-1326.

Fetter, C.W., 1980. Applied hydrogeology. Charles E. Merill Publishing, Toronto.

Flemings, P.B., Long, H., Dugan, B., Germaine, J., John, C., Behrmann, J.H., Sawyer, D., Expedition IODP, 2008. Pore fluid overpressure measured with penetrometers on the continental slope, Gulf of Mexico. Earth and Planetary Science Letters 269, 309-324.

Fleury, P., Bakalowicz, M., de Marsily, G., 2007. Submarine springs and coastal karst aquifers: a review. Journal of Hydrology 339 (1), 79-92.

Frank, T.D., Lohmann, K.C., 1995. Early cementation during marine-meteoric fluid mixing: Mississippian Lake Valley Formation, New Mexico. Journal of Sedimentary Research A65, 263-273.

Gold, D.P., Hall, R., Burgess, P., BouDagher-Fadel, M.K., 2014. The Biak Basin and its setting in the Bird's Head region of West Papua. Proceedings, Indonesian Petroleum Association Thirty-Eighth Annual Convention and Exhibition, IPA14-G298:448-460

Gold, D.P., Burgess, P.M., BouDagherFadel, M.K., 2017. Carbonate drowning successions of the Bird's Head. Facies 63(4), 25.

Green, A.N., Goff, J.A., Uken, R. 2007. Geomorphological evidence for upslope canyon-forming processes on the northern KwaZulu-Natal shelf, SW Indian Ocean, South Africa. Geo-Marine Letters 27, 399409 .

Grover, G., Jr, Read, J.F., 1983. Paleoaquifer and deep burial related cements defined by regional cathodoluminescent patterns, Middle Ordovician carbonates, Virginia. AAPG Bulletin 67, 1275-1303.

Hendardjo, K.S., Netherwood, R.E., 1986. Palaeoenvironmental and diagenetic history of Kais Formation, KBSA, Irian Jaya. Proceedings Indonesian Petroleum Association, 15th Annual Convention and Exhibition, Jakarta, 423-438.

Hill, K.C., Gleadow, A.J.W., 1989. Uplift and thermal history of the Papuan Fold Belt, Papua New Guinea: Apatite fission track analysis. 
Australian Journal of Earth Sciences 36(4), 515-539.

Hovland, M., Judd, A.G., 1988. Seabed pockmarks and seepages. Impact on geology, biology and the marine environment. Graham and Trotman Ltd., London.

Hutchinson, J. N., 1968. Mass movement. In: Fairbridge, R.W. (Ed.), Encyclopedia of Geomorphology. von Nostrand Reinhold, New York, 1295 pp.

Irwin, H., Curtis, C., Coleman, M., 1977. Isotopic evidence for source and diagenetic burial of organic-rich sediments. Nature 269, 209213.

Johnson, D., 1939. The Origin of Submarine Canyons: A Critical Review of Hypotheses. Columbia University Press, New York.

Kohout, F. A., 1966. Submarine springs. In: Fairbridge, R. W. (Ed.) Encyclopedia of the Earth Sciences, Vol. 1, Oceanography, von Nostrand Reinhold, New York, 878-883.

Le Pichon, X., Şengör, A.M.C., Demirbağ, E., Rangin, C., Imren, C., Armijo, R., Görür, N., Çağatay, N., De Lepinay, B.M., Meyer, B., Saatç1lar, R., 2001. The active main Marmara fault. Earth and Planetary Science Letters, 192(4), 595-616.

McAdoo, R.I., Haebig, J.C., 1999. Tectonic elements of the north Irian Basin. Proceedings Indonesian Petroleum Association, 27th Annual Convention and Exhibition, Jakarta, IPA99-G-150, 1-17.

McCrea, J.M., 1950. On the isotopic chemistry of carbonates and a paleotemperature scale. Journal of Chemical Physics 18 (6), 849-857.

Melim, L.A., 1996. Limitations on lowstand meteoric diagenesis in the Pliocene-Pleistocene of Florida and Great Bahama Bank: Implications for eustatic sea-level models. Geology 24(10), 893-896.

Memmo, V., Bertoni, C., Masini, M., Alvarez, J., Imran, Z., Echanove, A., Orange, D., 2013. Deposition and deformation in the recent Biak Basin (Papua Province, Eastern Indonesia). Proceedings Indonesian Petroleum Association Thirty-Seventh Annual Convention and Exhibition, IPA13G-122

Meyers, W.J., Lohmann, K.C., 1985. Isotope geochemistry of regionally extensive calcite cement zones and marine components in Mississippian limestones, New Mexico. In: Schneidermann, N., Harris, P.M. (Eds.) Carbonate Cements. SEPM Special Publication 36, 223-239.

Milton, D. J., 1973. Water and processes of degradation in the Martian landscape. Journal of Geophysical Research 78, 40374047.

Moore, C.H., Wade, W.J., 2013. Carbonate reservoirs: porosity and diagenesis in a sequence stratigraphic framework 2nd Edition. Elsevier, Amsterdam.

Niemann, J.C., Read, J.F., 1987. Regional cementation from unconformity-recharged aquifer and burial fluids, Mississippian Newman Limestone, Kentucky. AAPG Bulletin 58, 688-705.

Orange, D.L., Anderson, R.S., Breen, N., 1994. Regular submarine canyon spacing in the submarine environment: the link between hydrology and geomorphology. GSA Today 4,36-39.

Orange, D.L., Breen, N.A., 1992. The effects of fluid escape on accretionary wedges 2 . Seepage force, slope failure, headless submarine canyons, and vents. Journal of Geophysical Research: Solid Earth, 97(B6), 9277-9295.

Pairault, A.A., Hall, R., Elders, C.F., 2003. Structural Styles and Tectonic Evolution of the Seram Trough, Indonesia. Marine and Petroleum Geology 20, 1141-1160.

Paull, C.K., Spiess, F.N., Curray, J.R., Twichell, D.C., 1990. Origin of Florida Canyon and the role of spring sapping on the formation of submarine box canyons. Geological Society of America Bulletin, 102(4), 502-515.

Paull, C.K., Neumann, A.C., 1987. Continental margin brine seeps: Their geological consequences. Geology 15, 545-548.

Person, M., Dugan, B., Swenson, J.B., Urbano, L., Stott, C., Taylor, J., Willett, M., 2003. Pleistocene hydrogeology of the Atlantic continental shelf, New England. GSA Bulletin 115, 1324-1343.

Quinn, T.M., 1991. Meteoric diagenesis of PlioPleistocene limestones at Enewetak atoll. Journal of Sedimentary Research 61(5), 681703. 
Redmond, J.L., Koesoemadinata, R.P., 1976. Walio oil field and the Miocene carbonates of Salawati basin, Irian, Jaya, Indonesia. Proceedings Indonesian Petroleum Association, 5th Annual Convention and Exhibition, Jakarta, 41-57.

Robb, J.M., 1984. Spring sapping on the lower continental slope, offshore New Jersey. Geology 12, 278-282

Robb, J.M., 1990. Groundwater processes in the submarine environment: Groundwater Geomorphology: The Role of Subsurface Water in Earth-Surface Processes and Landforms. Geological Society of America Special Paper 252, 267-282.

Sangrey, D.A., 1977. Marine geotechnology: stateof-the-art. Marine Geotechnology 2, 45-80.

Scholle, P. A., Ulmer-Scholle, D. S., 2003. A Color Guide to the Petrography of Carbonate Rocks: Grains, textures, porosity, diagenesis. American Association of Petroleum Geologists Memoir 77, Tulsa, OK

Shackleton, N.J., Kennett, J.P., 1975. Palaeotemperature history of the Cenozoic and the interior of Atlantic Glaciation: oxygen and carbon isotope analyses in DSDP sites 277, 279 and 281. Initial Report DSDP 29, 743-753.

Small, R. J., 1965. The role of spring sapping in the formation of Chalk escarpment valleys, Southampton Research Series in Geography 1, 3-29.

Spakman, W., Hall, R. 2010. Surface deformation and slab-mantle interaction during Banda arc subduction rollback. Nature Geoscience $3,562-566$.

Tucker, M.E., Wright, V.P., 1990. Carbonate sedimentology. Blackwell Science, UK.

Wu, Y., Chafetz, H.S., 2002. Stable isotopic signature of a palaeoaquifer, mississippian Alamogordo Member limestones, sacramento mountains, New Mexico, USA. Sedimentology 49(2), 227-235.

Yun, J.W, Orange, D.L., Field, M.E., 1999. Subsurface gas offshore of northern California and its link to submarine geomorphology. Marine Geology 154, 357368. 